\title{
The Underlying Reasons of Hardly Excluding Illegally Obtained Evidence in China
}

\author{
Wang Chao \\ College for Criminal Law Science, Beijing Normal University, \\ China. \\ Email: wangchao [AT] bnu.edu.cn
}

\begin{abstract}
Although Chinese exclusionary rule reform made significant progress in technology, China does not fundamentally change the operating environment of exclusionary rule. With respect to the function of criminal court hearing, it is difficult for us to find ample scope for the exclusionary rule. On the one hand, the particular mutual coordination among investigators, procuratorates and courts in China, and the criminal procedure structure centered on the pretrial procedure basically determine that it is difficult for the defense party to completely overthrow the procuratorate's prosecution through applying for excluding illegally obtained evidence. Even if the defense party can occasionally impel the court to exclude illegally obtained evidence by forceful evidence, the defendant fails to change the result of being convicted. On the other hand, in the case of a formalistic court investigation and the phase separation between hearing and adjudicating, coupled with excessive emphasis on the truth of a case fact, the exclusionary rule with the high expectations of the whole society still exists in name only as before.
\end{abstract}

Keywords--- The exclusionary rule; application dilemmas; formalistic trial

\section{INTRODUCTION}

In modern criminal procedure, the exclusionary rule may be the most important rule of evidence. To some extent, how to establish the exclusionary rule is a direct reflection of the degree of civilization in a national criminal justice system. Affected by the traditional concept of punishing crime and other factors, Chinese legislature had not always really established the exclusionary rule before 2012. Furthermore, although the 1979 Criminal Procedure Law (P. R. C) art.32 and the 1996 Criminal Procedure Law (P. R. C) art.43 explicitly require that criminal investigators can not collection evidence through torture, threats, inducements, deception or other illegal means, Chinese legislature did not provide the legal consequences for these unlawful investigations. However, because national prosecution authorities can be free to use illegally obtained evidence, torture and other illegal investigative behaviors have become a repeated phenomenon. In view of this, the Supreme People's Court (SPC) and Supreme People's Procuratorate (SPP) provided the legal consequences for unlawful investigations when issuing judicial interpretations about the 1996 revisions to the China's Criminal Procedure Law (CPL). Specifically, according to Interpretation on Several Issues in the Implementation of the Criminal Procedure Law art. 61 (issued by the SPC, June 29, 1998) and the Criminal Procedure Rules for People's Procuratorates art. 265 (issued by the SPP, Jan. 18, 1999), a confession of a criminal suspect or defendant and a witness or victim statement obtained through torture, threats, inducements, deception or other illegal means shall be excluded and not be used as a basis for a prosecution decision and a sentence.

The SPC and SPP established the exclusionary rule by the above judicial interpretations, but it was never implemented in judicial practice. On the one hand, torture and other unlawful investigations still occur frequently. On the other hand, a defendant or a defender often alleges that evidence for the prosecution is obtained through illegal means, but in most cases, their allegations are dismissed by the court in the end. Theoretical circles universally attribute the nominal exclusionary rule to its own shortcomings, such as its limited scope, the lack of procedural rules and the ambiguity of unlawful investigations. ${ }^{1}$ In this context, the SPC, SPP, Ministry of Public Security, Ministry of State Security and Ministry of Justice promulgated Rules on Certain Issues Relating to the Exclusion of Illegal Evidence in Criminal Cases on June 13, 2010. This judicial interpretation provides the exclusionary rule in detail, such as its application phases, the scope of illegally obtained evidence, and burden of proof in the exclusionary rule. Based on that judicial interpretation, the 5th Session of the Eleventh National People's Congress systematically provided the exclusionary rule at the legislative level for the first time when amending the CPL on March 14, 2012. Especially with the continuous deepening of criminal justice reform, the SPC and SPP jointly formulated new judicial interpretations in order to further improve the exclusion rule. For example, the SPC, SPP, Ministry of Public Security, Ministry of State Security and Ministry of Justice jointly promulgated Several Issues concerning the Strict Exclusion of the Illegally Collected Evidence in the Handling of Criminal Cases on

1 Zhou jing \& Wang chao, Retrospect and Rethinking on the Law of Criminal Evidence with Some Considerations on the Transformation of Its Research Method, 2004: 3, PEKING UNIVERSITY LAW JOURNAL, 369. 
June 20, 2017.

Obviously, China's exclusionary rule reform has made significant progress at the institutional level. For this reason, all sectors of society have expressed a great many words of praise for the exclusionary rule reform. However, judging from the judicial practice in recent years, the exclusionary rule after refinement and revision still does not get rid of the fate of being in name only. Even if the people's courts can occasionally exclude illegally obtained evidence, it is based on the premise that the exclusion of illegally obtained evidence does not affect the conviction in most cases. Why is it still very difficult for the people's courts to exclude illegally obtained evidence in the case that the exclusionary rule has been continuously improved? In my opinion, the underlying reason is that China only pays too much attention to the technical rules for excluding illegally obtained evidence, but does not fundamentally change the operating environment that affects the implementation of the exclusionary rule in the process of reforming the exclusionary rule.

\section{THE PEOPLE'S COURT'S LACK OF AUTHORITY TO EXCLUDE ILLEGALLY OBTAINED EVIDENCE}

In the case where excluding illegally obtained evidence often hinders finding truth, the people's courts must have adequate authority when excluding illegally obtained evidence. If the people's courts lack authoritative status, it is unlikely that they will resolutely exclude illegally obtained evidence without considering the feeling of powerful investigative organs and procuratorates. In recent years, although an important goal of Chinese judicial reform is to improve the authority of the judiciary, the authority of the people's courts has not been established. Especially in the criminal trial process, it is very difficult for the people's courts to obtain sufficient authoritative status because they cannot surpass the traditional relationship among investigators, procuratorates and courts. However, in the case of the loss of authoritative status, it is only an expectation and value pursuit for the people's courts to exclude illegally obtained evidence.

\section{A. A Common Interest Community of Punishing Crimes}

In modern criminal procedure, the interrelationship among investigators, procuratorates and courts affects not only the impartiality of the process of criminal procedure but also the final outcome of criminal procedure. After all, the criminal procedure is a prosecution activity provoked to citizens by the country in the name of the overall interests of society. Meanwhile, criminal investigative authorities, procuratorial organizations and adjudication organizations are representatives of the State to exercise the corresponding state power. In criminal procedural activities, if the relationship among the above organizations cannot be rationalized, legitimate rights and interests of a defendant may be violated at any time, and the defendant will become a tool used to punish crimes.

Since 1949, the principle of "separation of functions, mutual coordination, and mutual checks" has always been regarded as the basic norm of mutual relations among a public security authority, a people's procuratorate and a people's court in China. In terms of mainstream ideas of scholars, this principle as the basic norm of constitution and the basic principle of CPL in China is not only the result of summing up judicial experience with Chinese characteristics but also the creation of following the guidance of Marxism-Leninism and Mao Zedong Thought. According to this principle, although a public security authority, a people's procuratorate and a people's court respectively stand for three different functions, namely, criminal investigations, prosecution and criminal trial, they are all politico-legal organizations and criminal judicial authorities on behalf of the State to exercise judicial power, and they commonly shoulder the task of punishing crimes. Admittedly, this arrangement is rational when the legal and judicial systems were not yet fully built in the early period of New China. However, with the continuous progress of the socialist legal system and the boom in human rights protection and procedural justice, the principle has been exposed to more and more problems. ${ }^{2}$ In point of the exclusionary rule, if nothing has been done to the above principle, it is difficult to ensure that a people's court will exclude illegally obtained evidence submitted by a people's procuratorate in accordance with statutory procedures. This is because under the influence of the above principle, in order to successfully complete shared responsibility of punishing crimes, a public security authority, a people's procuratorate and a people's court often form a common interest community of punishing crimes in criminal procedural activities, which will inevitably pose a deadly threat to the exclusionary rule.

First, in order to successfully achieve the common purpose of punishing crimes, the above three criminal judicial authorities often take how to accurately identify criminal facts as the primary issue in criminal procedural activities rather than whether the evidence is obtained by justified means. In this case, as long as they can accurately identify criminal facts and make sure that there is no obvious error in the final outcome of criminal procedure in judicial practice, illegal investigative actions can be tolerated and given a reasonable explanation. Under the underlying rule of "so long as a punishment is correct, it can be negligible whether the procedure is legitimate or not", the legal supervision of a people's procuratorate and the criminal trial of a people's court usually give way to the need of punishing crimes. In this case, a people's procuratorate and a people's court often turn a blind eye to the illegal investigative practices of criminal

2 Wang chao[王超], Fen gong fu ze hu xiang pei he hu xiang zhi yue yuan ze zhi fan si: yi cheng xu zheng yi wei shi jiao [Rethinking of the Principles of Division of Labor with Individual Responsibility, Mutually Cooperation and Mutually Condition: from the Angle of Procedural Justice分工负责、互相配合、互相制约原则之反思：以程序正义为视角]， 2005: 2 Fa shang yan jiu [STUDIES IN LAW AND BUSINESS《法商研究》] 19-25. 
investigators and still regard illegally obtained evidence as a basis for a prosecution decision or a sentence.

Secondly, in the common interest community of punishing crimes, a people's court not only need hear and decide criminal cases, but also shall coordinate with a people's procuratorate and a criminal investigative authority in order to complete their common task of punishing crimes, which makes a people's court often deviate from the neutral status and show a certain desire to prosecute in judicial practice. A people's court has actually evolved into a third prosecutor following a criminal investigative authority and a people's procuratorate in this case. Furthermore, a people's court should be the last bastion of social justice, but it usually stands together with an investigative authority and a people's procuratorate and becomes the last defense line of criminal judicial authorities punishing crimes. Therefore, we can hardly expect a people's court eager to complete the common aim of punishing crimes to withstand the pressure and exclude evidence illegally obtained by investigative authorities, which is very helpful to prove criminal facts. ${ }^{3}$

Finally, a people's court shall, from fair trial perspective, review the legitimacy of evidence for the prosecution submitted by an investigative authority and a people's procuratorate, and exclude illegally obtained evidence which meets the conditions of application of the exclusionary rule. However, since the above three criminal judicial authorities have formed a common interest community of punishing crimes, it is also difficult to imagine that the people's court can be freed from the yoke of how to accurately identify criminal facts and correctly make a judgment or from the chain of punishing crimes together in order to provide necessary space for the application of the exclusionary rule.

\section{B. The Criminal Procedure Structure Centered on the Pretrial Procedure}

In modern criminal procedure, though a judicial process seems the same from criminal investigation to prosecution and from prosecution to trial, the scientific structure of criminal procedure should center on the criminal trial procedure. On the one hand, based on the presumption of innocence and the function of dispute resolution, the criminal trial is the final and most important procedure in determining the fate of the accused. On the other hand, a criminal court is a "sound proof room" free from invasion by a variety of external factors. Moreover, it adopts the means that conform to procedural justice, such as the fair play between the prosecution and the defense, the common participation of the main parties and public hearing. Hence, compared to the unilateral prosecution of prosecution authorities for a suspect or a defendant, the results of criminal trial are more authoritative and acceptable without doubt. From this point of view, the criminal trial procedure as the center of the criminal procedure structure is an important foundation for application of the exclusionary rule, because only in this structure, it will be possible to form a virtuous cycle movement among a prosecution party, a defense party and a judge. In order to ensure the success of prosecution, a criminal investigative authority and a procuratorate must try to prosecute through legal or justified means; even if the legitimate rights and interests of the defense are violated by a criminal investigative authority and a procuratorate, he or she can obtain corresponding judicial remedies through the channels within the judicial system; a court dares to exclude illegally obtained evidence which objectively plays an important role to prove criminal facts by virtue of its authoritative status as final judgment in judicial process, and this will contribute to the cyclical running of prosecution activities on the legal track.

However, under the influence of the principle of "separation of functions, mutual coordination, and mutual checks", it does not produce a positive interactive relationship between the above three criminal judicial authorities, but forms the criminal procedure structure centered on the pretrial procedure through a flow process in China. On the one hand, a public security authority, a people's procuratorate and a people's court are independently and respectively engaged in judicial actions in the criminal investigation and the criminal trial. Because these three stages balance each other in criminal procedure, it is difficult for the criminal trial to become the center of criminal procedure. In this case, it is hard for a people's court to implement a truly effective judicial control and judicial review to the investigative and prosecution activities of a public security authority and a people's procuratorate. On the other hand, based on the common aim and relay relationship between the above three criminal judicial authorities, case file materials have a decisive impact on a criminal judgment. A criminal judgment to a certain extent has been reduced to the direct confirmation of a prosecution decision in this case. ${ }^{4}$ Obviously, this structure will exert a negative influence on the exclusionary rule.

On the one hand, in the criminal procedure structure centered on the pretrial procedure, a people's court is only the last operator of an assembly line with a public security authority, a people's procuratorate and a people's court punishing crimes hand in hand. Concretely speaking, the people's court is not engaged in independent review and judgment to a criminal prosecution standing in a neutral stance, but fills the role of locating and making up the deficiencies in the issue of punishing crimes and hypocritically makes the final and authoritative determination to the criminal prosecution through

3 Especially when the political status of a public security authority is often more important than a people's court's, the court usually does not easily exclude evidence for the prosecution because of the pressure of the public security authority and the people's procuratorate. See Chen rui hua [陈瑞华], shen pan zhi zhong de shen pan: cheng xu xing cai pan zhi chu bu yan jiu [Trail Within A Trial: A Primary Study on Judgment of Legitimacy of Criminal Procedure审判之中 的审判: 程序性裁判之初步研究], 2004: 3 Zhong wai fa xue [PEKING UNIVERSITY LAW JOURNAL 《中外法学》]357.

4 Chen rui hua [陈瑞华], xing shi su song de qian yan wen ti (di er ban) [Forward Position Problems of Criminal Procedure (the Second Edition) 《刑事诉讼的前沿问题》(第二版)] 333-341 (Zhong guo ren min da xue chu ban she, 2005). 
the formal criminal trial, and then finishes the last step of criminal sanction under the legal procedures. In this case, we can hardly expect a people's court to turn a blind eye to evidence illegally obtained by a public security authority and a people's procuratorate. Certainly, the court also will not exclude this evidence that can take an important role in proving criminal facts at the risk of offending them. After all, if the people's procuratorate has strong evidence to prove criminal facts and the people's court is able to determine that the criminal prosecution is correct, it will be not of great significance whether the court excludes illegal obtained evidence or not.

On the other hand, in the criminal procedure structure centered on the pretrial procedure, a defendant's fate is not determined by a people's court's criminal trial activities but by prosecution authorities. When a prosecution decision and materials submitted by a people's procuratorate actually have a pre-determined effect on the judgment of a people's court, the court would rather trust all the evidence submitted by the prosecution authorities than thoroughly review the exclusionary application of the defense party and then exclude illegally obtained evidence under the exclusionary rule.

\section{EXCLUSION SURVEY OF ILLEGALLY OBTAINED EVIDENCE WITHOUT SUSPENSE}

In order to guarantee fair trial, modern countries emphasize the unity of hearing and adjudicating, and the judges who personally participate in the trial process should make corresponding judgments according to the direct impression they obtained during the trial. Although Chinese exclusionary rule has made significant progress since 2010, in the case of separation between the trial and the judgment, the trial judge's court investigation of illegally obtained evidence has become a kind of form. The people's court can neither thoroughly ascertain whether there are illegal investigative practices, nor can it exclude the illegally obtained evidence for the prosecution.

\section{A. The Phase Separation between Hearing and Adjudicating}

From a legal principle, because a judge experiences the whole process of adducing evidence, cross examination and debate between prosecution and defense, and a criminal court is a "sound proof room" free from invasion of a variety of "external noises", he or she can calmly deliberate all evidence and make a more comprehensive and objective evaluation about the opinions of both parties, and thus make a more reasonable and accurate judgment on the case. Moreover, as previously noted, fair trial can make court judgments more acceptable by both parties. Perhaps because of that, China regarded criminal trial mode reform as a breakthrough point of criminal justice reform in the mid-1990s.

With the continuous progress of adversary system trial mode reform in China, the past bad situations, such as "judgment before trial" and the limited distinction between prosecution and trial, have improved a lot, but the weakened trial function, the formalistic court trial and other chronic illness still have not been completely eradicated, and China still has not formed a court culture that a judge makes a decision merely according to the cross-examination and debate between prosecution and defense in court. First of all, as mentioned earlier, as in the assembly-line style of the criminal procedure structure, the court trial to a certain extent has been degraded to a confirmation process of a prosecution decision. Since the results of criminal procedure has been defined in advance, a people's court would rather make a decision according to a prosecution decision or case file materials provided by a people's procuratorate than get engaged in tedious trial. Secondly, due to the lack of the hearsay evidence rule and the prevalence of transferring case file materials, the link between the prosecution case files and the court has not been completely cut off, which leads to the following undesirable effects: (1) the evidence adduced by both parties and their opinions in the court debate cannot exert considerable influence on the judgment conclusion; (2) the formation of criminal adjudication is not usually based on the impression made by a judge according to the evidence adduced by both parties and their opinions in the court debate, but on the fruit of going over files outside the courtroom. Finally, from the surface, a criminal courtroom is always engaged in hearing, and a written sentence is also made by a collegial panel or a sole-judge bench. However, because of the judicial committee, the examination and approval of cases, the requesting instructions of cases and other judicial systems, a collegial panel or a sole-judge bench often cannot exercise a real adjudication authority in their own cases. This is the phenomenon of "real hearers without adjudicating and real adjudicators without hearing" in China's criminal trial. In the case of the phase separation between hearing and adjudicating, it is difficult to find a shelter for the exclusionary rule.

On the one hand, if an adjudication conclusion is derived from outside the courtroom, the contents and process of criminal trial will be of little significance. In that case, a judge will have no interest in carefully considering whether a criminal trial process is in full compliance with the standards of procedural justice. From a trial judge's point of view, since he or she cannot decide the final result of a case anyway, he or she would rather perfunctorily deal with cases rather than thanklessly or hypocritically conducts tedious court trial in accordance with the standards of procedural justice. Under the influence of this mindset, the trial judge cares nothing about whether witnesses or investigators testify in court, and seems entirely insensible of whether there are illegal investigative activities. Thus, as described above, the following phenomena often occur in judicial practice: whether a defendant withdraws his previous confession on the grounds of torture and illegal actions or the defense party applies to a people's court for excluding illegally obtained evidence, a collegial panel or a solejudge bench will not notify relevant investigators to appear before court, nor will it initiate an investigation regarding the legality of evidence for the prosecution; the collegial panel or sole-judge bench would rather trust the legality and authenticity of all types of investigative records and written statements than accept a defendant's confession and defense in court, and in this case, it certainly will not exclude illegally obtained evidence provided by the prosecution party in 
accordance with the requirement of the defense party.

On the other hand, when the link between the prosecution case files and the court cannot be completely cut off, no matter the court initiates an investigation regarding the legality of evidence for the prosecution or not, it has ample opportunity and time to directly contact with illegal evidence presented by the prosecution party. When the trial judge has gone over case file materials of the prosecution party and formed an impression of the contents of illegally obtained evidence and especially evidence for the prosecution convinces the trial judge of a defendant's guilt, he or she will not care much about whether to exclude illegally obtained evidence. In addition, although the court shall initiate a specialized investigation and debate regarding illegally obtained evidence in accordance with the 2012 CPL art.56, because this investigation and debate is embedded in the hearing procedure that is used to resolve the problem of conviction and sentencing, and public prosecutors can be free to use a variety of written materials, the procedural issue of whether to exclude illegally obtained evidence will inevitably be submerged in the legality and authenticity of all types of investigative records and even transformed into the substantial issue of whether a defendant's criminal facts has been proven. In this case, it is difficult for the court to firmly exclude illegal obtained evidence which can prove the criminal facts.

\section{B. A Truth-centered Mode of Thinking}

In criminal procedure, in term of both the punishment of crimes and human rights protection, it is very significant to determine the truth in criminal cases. Merely in point of the accuracy of fact-finding, either in theory or experience, it is very hard to say that the case facts determined by a court are superior to the ones ascertained by an investigative authority. However, in modern criminal procedure, a court can make an authoritative conclusion only after trial, and it is impossible for the court to directly make a decision according to the case facts ascertained by an investigative authority. It is because that the court follows the principle of procedural justice and the judgment is the result of the common participation of the prosecution party, the defense party and the court; while in most cases, the case facts ascertained by prosecution authorities are the product of being unilaterally and secretly identified. Furthermore, even if the case facts determined by a court have some differences from the original appearance of criminal facts, they are acceptable. However, even though the case facts ascertained by prosecution authorities are consistent with the original appearance of criminal facts, they are unconvincing. According to the American scholar Mashaw's "Dignitary Theory", the main reason why a huge gap exists here is that the former are able to ensure that those people whose interests may be subject to the direct impact of the results of the criminal procedure have the opportunity of meaningfully participating in the whole criminal procedure, therefore they can exert a positive impact on the outcome of criminal procedure, which makes their dignities and litigation status in criminal procedure be respected. It means that the top concern is not whether the criminal facts can be found out, but whether the means of fact-finding are acceptable and convincing. Only in this way can the exclusionary rule have sufficient living space. After all, the main purposes of the exclusionary rule established by the modern countries are to maintain procedural justice, protect human rights, promote the rule of law, and deter illegal actions and other considerations instead of making sure how to find out the truth. Furthermore, only when a court holds that procedural justice, human rights protection and other value targets are more worthy to be maintained than the truth of the case facts, it will be possible that a court indeed excludes illegally obtained evidence which shall be excluded in accordance with the requirements of the exclusionary rule.

However, under the influence of dialectical materialism, criminal judicial activities are seen as cognitive activities in China. Therefore, the central task of a public security authority, a people's procuratorate and a people's court is to find out the truth according to the basic laws of epistemology and make correct decisions in accordance with the truth. From the perspective of pursuing the truth, criminal trial is only the continuation of a criminal investigation and prosecution in factfinding. In this case, a judge has become the last operator of the assembly line of seeking the truth. In order to find out the truth and ensure the correctness of a criminal procedure's result, a judge shall positively act as the discoverer of the case facts like an investigator and public prosecutor, and gather various kinds of evidence that can prove the guilt or innocence of a criminal suspect or defendant under legal procedures; a judge can actively question a defendant, a victim, a witness, and other litigation participants in the course of trial; a judge announces an adjournment and investigates and verifies evidence like a criminal investigator outside of a courtroom by conducting crime scene investigation, examination, seizure, impoundment, forensic identification or evaluation, property inquiry, and freezing of property. When a people' court takes how to find out truth as his responsibility, all the evidence or its obtained means that can prompt a judge to determine criminal facts will get his or her permission or tolerance; otherwise will get his or her obstruction or exclusion.

Obviously, if a people's court takes the truth-centered mode of thinking to understand and treat the exclusionary rule, it will have no incentive to exclude illegally obtained evidence. After all, much illegally obtained evidence objectively plays an important role in seeking the truth and proving criminal facts. Judicial practice has also repeatedly proved that in order to respect the objective truth and guarantee a correct judgment, a judge would rather take into account the accuracy of evidence for the prosecution than review the legality and validity of the prosecution activities during trial. In this case, when facing illegally obtained evidence submitted by a people's procuratorate, if it is precisely helpful to prove criminal facts, a people's court often inclines to ignore the exclusionary rule and accepts it. Likewise, because the accuracy of factfinding is the inherent premise of a prosecution, when discovering illegal evidence obtained by a criminal investigative

5 See Jerry L. Mashaw, Due Process in the Administrative State (first edition) , Yale University Press, 1985 , pp.158170. 
authority during examination and prosecution, it is impossible for a people's procuratorate to exclude it in order not to affect to ascertain criminal facts. Consequently, if we still hold the concept of "as long as the truth of the case facts can be guaranteed, procedural justice is an optional vase" and fail to thoroughly change a truth-centered mode of thinking in China's criminal judicial practice, we are unlikely to find ample scope for the exclusionary rule.

\section{CONCLUSION}

When social elites are cheering for the near-perfect exclusionary rule, reflective thinking against the new rule in this paper may seem untimely. However, expected purposes cannot be equated with actual results. Because the exclusionary rule is the centralized reflection of value conflicts in modern criminal procedure, its realization isn't once and for all. We may have the ability to work out the exclusionary rule which could be neck and neck with western countries on the basis of learning from the successful experience of foreign countries, but the implementation of the rule requires high operating costs, perfect system design, and a good operating environment. With the continuous development and progress of China's socialist legal construction, the bright blueprint drawn by social elites through the exclusionary rule for curbing torture and protecting human rights is indeed fascinating. However, we may feel much dejected when considering that the new rule will be confronted with the insurmountable barriers described in this paper. With respect to the function of criminal court hearing, it is difficult for us to find ample scope for the exclusionary rule. The exclusionary rule with the high expectations of the whole society still exists in name only as before. On the one hand, the particular mutual coordination among investigators, procuratorates and courts in China, and the criminal procedure structure centered on the pretrial procedure fundamentally determine that it is difficult for the defense party to completely overthrow the procuratorate's prosecution through applying for excluding illegally obtained evidence. Even if the defense party can occasionally impel the court to exclude illegally obtained evidence by forceful evidence, the defendant fails to change the result of being convicted. On the other hand, in the case of the phase separation between hearing and adjudicating, coupled with excessive emphasis on the truth of a case fact, the criminal court is only the performance arena for criminal investigative authorities, procuratorial organizations and adjudication organizations to punish crimes hand in hand. On this stage, producing evidence, crossexamination, and debate about the exclusion of illegally obtained evidence are only the shame cloth of fair trial and the exclusionary rule, and it is very difficult for the defense party to challenge the legality of evidence for the prosecution. Therefore, the desire of the defense party to exclude illegally obtained evidence remains in people's imagination in most cases.

\section{REFERENCES}

- James J. Tomkovicz (2011), Constitutional Exclusion: The Rules, Rights, and Remedies that Strike the Balance Between Freedom and Order, London: Oxford University Press ;

- Tracey Maclin (2012), The Supreme Court and the Fourth Amendment's Exclusionary Rule, London: Oxford University Press ;

- Stephen C. Thaman (Ed.) (2013), Exclusionary rules in comparative law, Germany: Springer;

- $\quad$ LIU Guang-san (Ed.) (2015). Criminal Evidence Law, Beijing: China Renmin University Press;

- WANG Chao (2014). THE UTOPIA OF EXCLUDING ILLEGALLY OBTAINED EVIDENCE, Beijing: Law Press;

- $\quad$ BIAN Jian-lin and YANG Yu-guan (Ed.) (2012), Empirical Research on the Exclusionary Rule, Beijing: China University of Political Science and Law Press;

- LANG Sheng (Ed.) (2012). The Interpretation on the Criminal Procedure Law of the People's Republic of China (Latest Revised Revision), Beijing: Law Press;

- CHEN Rui-hua (2012). Criminal Evidence Law, Beijing: Peking University Press;

- $\quad$ SONG Ying-hui (Ed.) (2012). Detailed Interpretation on the Criminal Procedure Law of the People's Republic of China, Beijing: China University of Political Science and Law Press;

- $\quad$ LONG Zong-zhi (Ed.) (2011). Research on the China's Criminal Evidence Rules, Beijing: Zhong Guo Jian Cha Press;

- $\quad$ ZHANG Jun (Ed.) (2010). Understanding and Application for Criminal Evidence Rules, Beijing: Law Press;

- CHEN Rui-hua (2005). Forward Position Problems of Criminal Procedure (the Second Edition), Beijing: China Renmin University Press;

- CHEN Rui-hua (2003). Between Problems and Doctrine: Research on the Fundamental Problems in Criminal Procedure, Beijing: China Renmin University Press. 